\title{
Study of some biochemical parameters and productivity of Silphium L. genotypes as perspective energetic crops
}

\author{
D. B. Rakhmetov*, 0. M. Vergun, S. 0. Rakhmetova, 0. V. Shymanska, V. V. Fishchenko \\ M. M. Gryshko National Botanical Garden, NAS of Ukraine, 1 Tymiriazievska St., Kyiv, 01014,_Ukraine, "e-mail:jamal_r@bigmir.net
}

Purpose. This study was aimed to determine some biochemical parameters and productivity of the gene fund of Silphium L. genus in the M. M. Gryshko National Botanical Garden of the NAS of Ukraine. Methods. Plant raw material investigated at the flowering stage (17 genotypes) and the end of vegetation (20 genotypes) of Silphium spp. 3 species and 4 cultivars studied for the content of nutrients at the flowering. Determination of dry matter, ash, calcium, nitrogenfree extractives conducted according to Hrytsaienko et al. (2003), phosphorus, protein - according to Pochinok (1976), sugars - according to Krishchenko (1983), cellulose - according to Zheng et al. (2018), lipids - according to Zamowski, Suzuki (2004). It was used productivity parameters: yield of above-ground mass, the yield of dry mass, energetic value, yield of energy. Data analyzed statistically. Results. Investigation of nutrients content showed that content of dry matter was in the range of $18.90-29.3 \%$, protein - in the range of $8.88-23.56 \%$, cellulose $-15.10-36.14 \%$, ash $-8.13-12.19 \%$, lipids - 1.83-3.97\%; yield of above-ground mass - 45.0-139.0 t/ha, the yield of dry matter - 10.31-36.92 t/ha, energy value $-3933-4249 \mathrm{cal} / \mathrm{g}$, and yield of energy $-43.81-149.27 \mathrm{Gcal} / \mathrm{ha}$. A study of genotypes at the flowering and end of vegetation identified that the content of dry matter for all samples was in a range of 18.38-67.49\%, sugars $-2.78-19.0 \%$, ash $-3.93-11.20 \%$, calcium - 1.68-5.99\%, phosphorus $-0.14-1.21 \%$, energy value - 3153.36$3770.28 \mathrm{cal} / \mathrm{g}$. Conclusions. Plant raw material of genotypes of Silphium L. spp. is a valuable source of nutrients. The content of ash, its components, energetic value, and parameters of productivity depending on genotype and stage of growth. The results allow recommending selected Silphium genotypes as perspective energetic crops in Ukraine as well as other countries.

Keywords: Silphium; genotypes; energetic value; productivity; ash.

\section{Introduction}

Natural flora includes an inexhaustible gene fund that can be used in the introductive and selective process more actively to create valuable varieties and cultivars for practical use [1].

Last time numerous scientists indicated on the advantages of growing of representatives of Silphium L. (cup flower) as a highly adaptive and perspective energetic crop that from the second year of vegetation provide 13-20 t/ha of

\section{Dzhamal Rakhmetov}

https://orcid.org/0000-0001-7260-3263

Oksana Shymanska

https://orcid.org/0000-0001-8482-5883

Olena Vergun

https://orcid.org/0000-0003-2924-1580

Svitlana Rakhmetova

https://orcid.org/0000-0002-0357-2106

Valentina Fishchenko

https://orcid.org/0000-0003-3647-7858 absolutely dry mass [1-3]. Some authors denoted that these plants are native to America and about 12 species of Silphium are aboriginal plants of the prairies of the northern United States and Canada [4-6]. In Ukraine, these species are known as cultural plants [7].

Cup flower plants demonstrated high potential in the production of bioenergy in the South and North of America, Europe. S. perfoliatum is an extremely perspective crop for biogas production throughout Europe due to high yield of biomass, durability (up to 25 years), and the ability to grow in marginal lands [8-12]. Also, these species known as valuable forage, technical, honey, ornamental and phytomeliorative crops [8].

As energy plants, highly productive varieties and hybrids of cup flower plants can provide phyto raw materials yield up to $200 \mathrm{t} / \mathrm{ha}$, dry matter yield - up to $35 \mathrm{t} / \mathrm{ha}$, conventional phytofuels up to $30 \mathrm{t} / \mathrm{ha}$, biogas yield -20 thousand $\mathrm{m}^{3} /$ ha, biofuel calorific value - up to $4500 \mathrm{kcal} / \mathrm{kg}$ and energy yield from 1 ha over 
60 Gcal [13-15]. It was found that the application of mineral fertilizers, in particular nitrate, affects the energy yield of $S$. perfoliatum biomass [16].

Plants of S. laciniatum L. use at all as ornamental and medicinal and create interspecific hybrids with $S$. terebinthianaceum on the border of overlapping of their ranges [17]. S. tere binthianaceum growth in the natural flora of Indiana, southern Michigan, northern Wisconsin, and Missouri. It is distributed on both plains and mountain prairies and cultivated as a drought-resistant medicinal plant [17].

Extracts of cup flower herb demonstrated diuretic activity and able to decrease the cholesterol level. Herb of this plant is used in folk and traditional medicine as a diaphoretic, tonic, and kidney disease. Also, fresh herbs are used in homeopathy. Plant raw material of Silphium perfoliatum contains caffeic, p-coumaric, p-hydroxybenzoic, vanillic, etc. phenolic acids $[18 ; 19]$. Extracts of these plants show antioxidant, antibacterial, immunomodulatory activity [20]. The lipid fraction of the seeds of these plants contains $44 \%$ linolenic and $13.2 \%$ oleic fatty acids [21].

Previous reports showed that more attention was paid to research and the use of $S$. perfoliatum among other species in Ukraine as well as in the world $[3 ; 10]$. Based on many-years observations and obtained data about introductive and selective studies of Silphium spp. in the M. M. Gryshko National Botanical Garden of the NAS of Ukraine it should be noted that will be relevant a comprehensive study of individual species and created genotypes in the conditions of a specific agroclimatic zone of Ukraine.

The goal of this study was to determine and compare certain biochemical parameters and selected aspects of productivity of the plant raw material of Silphium L. genotypes as perspective crops in Ukraine and the world.

\section{Material and methods \\ Plant material}

The investigation was conducted in the M. M. Gryshko National Botanical Garden of the NAS (NBG) of Ukraine during 2018-2020. In this study used plant raw material of Silphium L. (cup plant) genotypes that represented the gene fund of these plants: $S$. perfoliatum L., var. PP-1; S. perfoliatum, var. PP-2; S. perfoliatum, var. NRK-7; S. perfoliatum, var. SR-6; S. perfoliatum, cv. Bogatyr; S. perfoliatum, cv. Peremozhets; S. perfoliatum, cv. Kanadchanka; $S$. perfoliatum $\times S$. integrifolium; S. integrifolium Michx., var. GD-5; S. integrifolium, var.
GKR-1; S. integrifolium, var. LPL-4; S. integrifolium, f. EBSFS; S. integrifolium, cv. Yuvileinyi-90; S. integrifolium $\times$ S. trifoliatum L.; S. laciniatum L.; S. laciniatum, f. 1; S. laciniatum, f. 2; S. laciniatum, var. PL-3; S. trifoliatum L.; S. trifoliatum $\times$ S. integrifolium; $S$. terebinthinaceum Jacq.; S. asperrimum Hook.

Plants took for analyses at the stages of flowering and the end of vegetation [22].

\section{Study of plant productivity}

Field experiments were established by the existing methods for the State Variety Network and research institutions lasting from three to six years in four replications. The size of sown plots is $60-100 \mathrm{~m}^{2}$, their registration area is $30-60 \mathrm{~m}^{2}$. The placement of variants on repetitions depending on the experiment is systematic and randomized [23]. It was conducted measurement of plant mass (yield).

\section{Biochemical analyses}

Biochemical analyses were carried out in the biochemical laboratory of the Cultural Flora Department of NBG. The dry matter is determined by the drying at the temperature of $105{ }^{\circ} \mathrm{C}$ till constant mass. The content of ash was investigated by the method of combustion of the samples in the muffle oven (SNOL 7.21100 , Termolab) at the $200-500{ }^{\circ} \mathrm{C}$. After combustion, the ash is used for the determination of calcium and phosphorus content by titrimetric methods. Ash was dissolved in hydrochloric acid solution to determine total calcium content. After the routine procedure described in the method, a solution was titrated by Trilon-B in the presence of hydroxylamine and murexide [24].

Ash was dissolved in the nitric acid solution to determine the total phosphorus content. After adding molybdenum acid ammonium, a solution of potassium oxalate, all mixture was titrated by sodium hydroxide in presence of phenolphthalein [25].

The total content of sugars determined by the Bertrand method with the use of Fehling solutions [26]. The content of protein is carried out by chloramine method [25], cellulose - by washing $4 \%$ sulphuric acid and $2 \%$ sodium hydroxide [27], nitrogen-free extractives - by [24], lipids - with Soxhlet apparatus in petroleum ether according to [28] with slight modification. Caloricity of raw measured on the calorimeter IKA C-200 (benzoic acid as standard). Obtained data analyzed with Microsoft Excel Software and given as averages and standard deviation of the mean. Data represented in Table 1 and Figures 1-6. 


\section{Results and discussion}

In the Cultural Flora Department of the NBG last decades conducted the comprehensive introduction and selection study with the species of Silphium L. genus, as a result of which were cultivars (4), varieties and forms (11), and interspecific hybrids (4) [22]. Results of the many-years investigations conducted in the NBG showed that phyto raw of these plants is a valuable source of nutritive compounds such as vitamins, sugars, cellulose, protein, etc. $[1,7,29] .100 \mathrm{~kg}$ of green mass of these plants contains the 14-16 feed units, one of which includes 140-160 $\mathrm{g}$ of digestible protein [7].

Investigation of biochemical composition and peculiarities of nutrient accumulation is an important direction for the evaluation of plant raw material, especially as forage.

It is established that the above-ground mass yield of investigated genotypes of Silphium spp. was from 45 (S. asperrimum) to 126 (S. in tegrifolium, cv. Yuvileinyi-90) t/ha, dry matter yield - from 10.31 (S. asperrimum) to 36.92 (S. integrifolium, cv. Yuvileinyi-90) t/ha (Table 1). The highest yield of above-ground mass had S. perfoliatum, cv. Peremozhets, the highest dry matter yield - S. integrifolium, cv. Yuvileinyi-90. S. asperrimum $(4249 \mathrm{kcal} / \mathrm{kg})$ characterized by the most caloricity, while the least found for S. perfoliatum, cv. Peremozhets (3933 kcal/kg). The maximal yield of energy determined for $S$. integrifolium, cv. Yuvileinyi-90 (149.27 Gcal/ha) and minimal - for S. asperrimum (43.81 Gcal/ha).

Energetic productivity of the plants of Silphium L. genus depending on genotype at the stage of start of budding-flowering

\begin{tabular}{|c|c|c|c|c|}
\hline Species, cultivar & Yield of above-ground mass, $\mathrm{t} / \mathrm{ha}$ & Yield of dry matter, $\mathrm{t} / \mathrm{ha}$ & Caloricity, kcal/kg & Yield of energy, Gcal/ha \\
\hline S. asperrimum & 45.0 & 10.31 & 4249 & 43.81 \\
\hline S. integrifolium, & & & & \\
\hline cv. Yuvileinyi-90 & 126.0 & 36.92 & 4043 & 149.27 \\
\hline S. lacinatum & 54.0 & 11.88 & 4175 & 49.60 \\
\hline $\begin{array}{l}\text { S. perfoliatum, } \\
\text { cv. Bogatyr }\end{array}$ & 119.0 & 25.23 & 4175 & 105.34 \\
\hline S. perfoliatum, & & & & \\
\hline $\begin{array}{l}\text { cV. Peremozhets } \\
\text { S. perfoliatum }\end{array}$ & 139.0 & 30.58 & 3933 & 120.27 \\
\hline cv. Kanadchanka & 106.0 & 20.03 & 3979 & 79.70 \\
\hline S. terebinthinaceum & 97.0 & 25.71 & 4192 & 107.78 \\
\hline $\mathrm{LSD}_{0,05}$ & 2.25 & - & - & - \\
\hline
\end{tabular}

According to Bury et al. (2020), the yield of biomass increased in the first two years of full vegetation [30]. As reported Kowalski (2007), the yield of biomass and dry matter at the cultivation of $S$. trifoliatum can give up to $28.8 \mathrm{t} / \mathrm{ha}$ of dry biomass [31]. In our study, this result was closed to $S$. perfoliatum, cv. Peremozhets.

The biochemical composition is also an important aspect concerning the introduction of energy crops. In this case, ash content and mineral composition are very useful [32]. Also, selected biochemical analyses were conducted with seventeen genotypes at the periods of flowering and end of vegetation as perspective energetic plants. The content of dry matter and total content of sugars at the flowering stage for seventeen genotypes of Silphium represented in Figure 1. Dry matter content at this stage was from 18.38 (S. perfoliatum, cv. Kanadchanka) to 34.77 (S. asperrimum) \% depending on the sample. The total content of sugars at the flowering stage was from 6.36 to $19.0 \%$ depending on genotype. The most sugars accumulated in raw of $S$. perfoliatum SR-6, the least - in hybrid S. integrifolium $\times$ S. perfoliatum.

One of the important parameters in the research of energetic plants is the total content of ash that is correlated with calorific value [33]. Ash is the remainder of unburned compounds, which obtained after the combustion of raw at high temperatures. Total ash it's a complex of mineral components, among which highlighted macro- and microelements [34]. Content of ash in the investigated genotypes at the flowering stage determined from 4.20 (S. perfoliatum, SR-6) to 8.12 (S. integrifolium, f. EBSFS) \% (Fig. 2). According to Franzaring et al. (2014), the content of ash in the raw $S$. perfoliatum was $15.4 \%$ [2]. Comparing with our investigation this parameter was approximately 2 times less. The content of calcium at the flowering stage was in a range from 1.68 (S. laciniatum, f. 2) to 3.38 (S. integrifolium, f. EBSFS) $\%$ and phosphorus - in a range from 0.42 


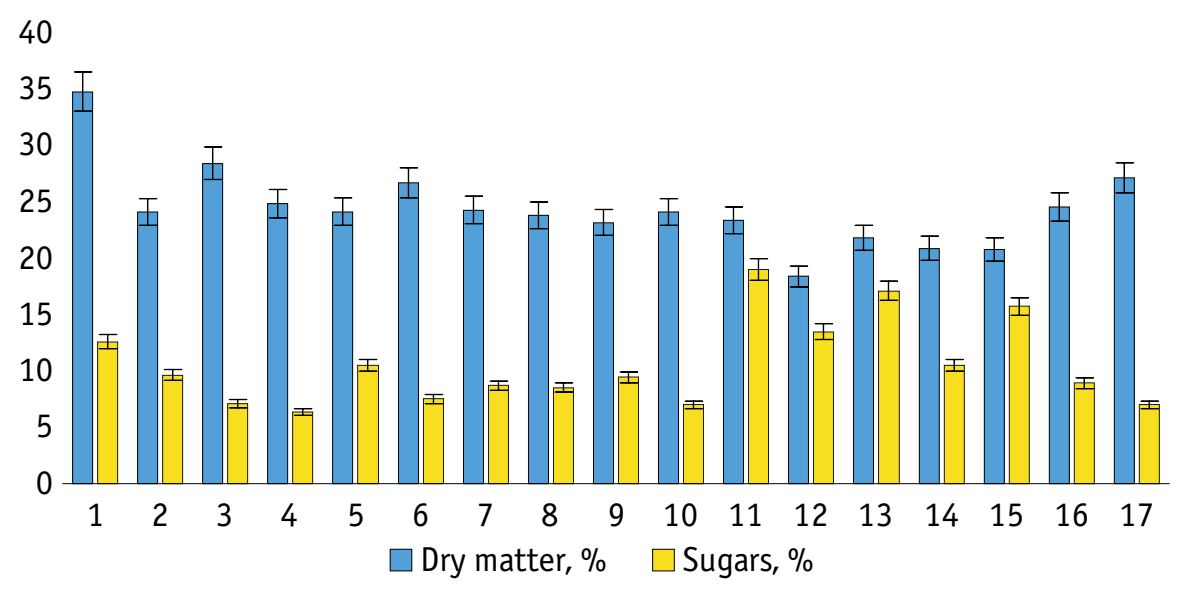

Figure 1. The dry matter content and total content of sugars in the raw of Silphium L. genotype at the period of flowering

(1 - S. asperrimum; 2 - S. integrifolium, f. EBSFS; 3 -S. integrifolium, GKR-1; $4-$ S. integrifolium $\times$ S. perfoliatum; 5 - S. integrifolium, cv. Yuvileinyi-90; 6 - S. integrifolium, LPL-4; 7 - S. integrifolium, GD-5; 8 - S. laciniatum, PL-3;

9 - S. laciniatum, f. 2; 10 - S. laciniatum, f. 1; 11 - S. perfoliatum, SR-6; 12 - S. perfoliatum, cv. Kanadchanka; 13 - S. perfoliatum, cv. Bogatyr; 14 - S. perfoliatum, PP-1; 15 - S. perfoliatum, PP-2; $16-$ S. trifoliatum $\times$ S. integrifolium; $17-$ S. trifoliatum)

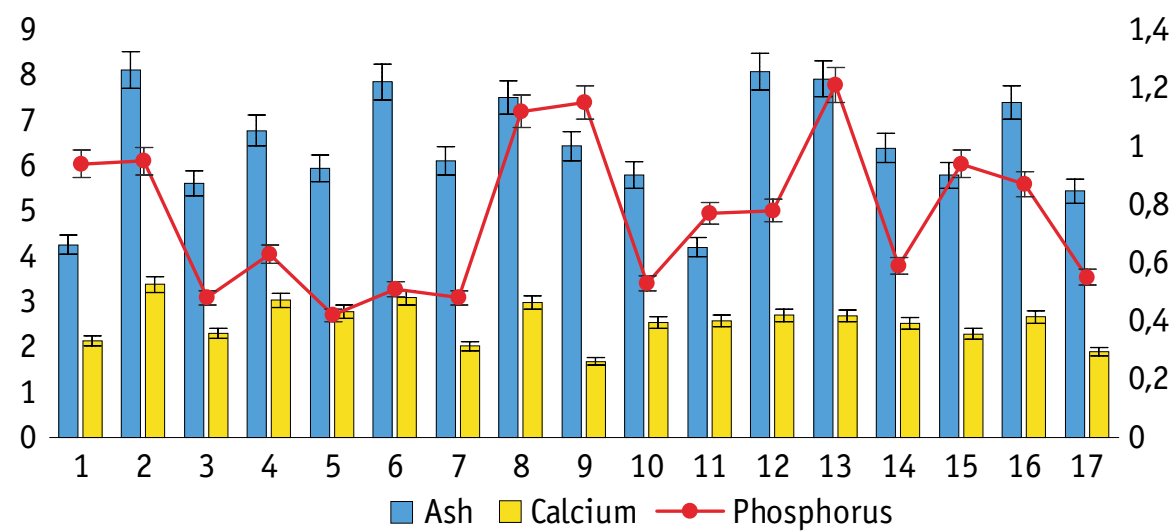

Figure 2. The content of ash, calcium and phosphorus (\%) in the genotypes of Silphium L. genus at the stage of flowering

(1 - S. asperrimum; 2 - S. integrifolium, f. EBSFS; 3 - S. integrifolium, GKR-1; $4-$ S. integrifolium $\times$ S. perfoliatum; 5 - S. integrifolium, cv. Yuvileinyi-90; 6 - S. integrifolium, LPL-4; 7 - S. integrifolium, GD-5; 8 - S. laciniatum, PL-3;

9 - S. laciniatum, f. 2; 10 - S. laciniatum, f. 1; 11 - S. perfoliatum, SR-6; 12 - S. perfoliatum, cv. Kanadchanka; 13 - S. perfoliatum, cv. Bogatyr; 14 - S. perfoliatum, PP-1; 15 - S. perfoliatum, PP- 2; $16-$ S. trifoliatum $\times$ S. integrifolium; 17 - S. trifoliatum)

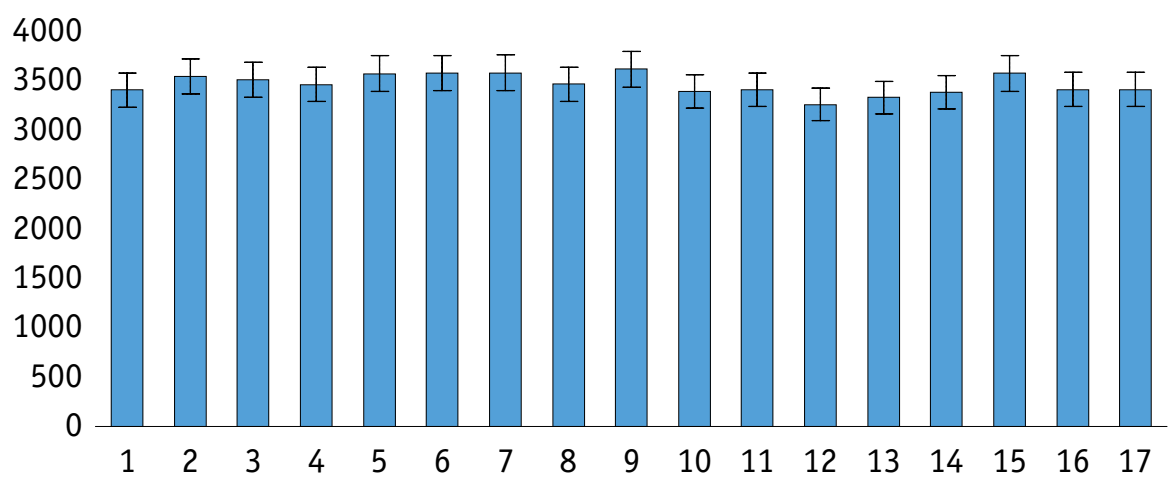

Figure 3. Energetic value of plants (cal/g) of different genotypes of Silphium $\mathrm{L}$. genus at the stage of flowering

(1 - S. asperrimum; 2 - S. integrifolium, f. EBSFS; 3 -S. integrifolium, GKR-1; $4-$ S. integrifolium $\times$ S. perfoliatum;

5 - S. integrifolium, cv. Yuvileinyi-90; 6 - S. integrifolium, LPL-4; 7 - S. integrifolium, GD-5; 8 - S. laciniatum, PL-3;

9 - S. laciniatum, f. 2; 10 - S. laciniatum, f. 1; 11 - S. perfoliatum, SR-6; 12 - S. perfoliatum, cv. Kanadchanka; 13 - S. perfoliatum, cv. Bogatyr; 14 - S. perfoliatum, PP-1; 15 - S. perfoliatum, PP-2; $16-$ S. trifoliatum $\times$ S. integrifolium; 17 - S. trifoliatum) 
(S. integrifolium, cv. Yuvileinyi-90) to 1.21 (S. perfoliatum, cv. Bogatyr) \%.

Bury et al. (2020) determined that the content of ash in the raw material of $S$. perfoliatum was from 2.84 to $4.46 \%$, the most of it determined in the seeds [30]. The energetic value of different genotypes of investigated plants at the stage of flowering was from 3253.21 to $3608.54 \mathrm{cal} / \mathrm{g}$ (Fig. 3). The higher value of caloricity determined for S. laciniatum, f. 2, and the less - for S. perfoliatum, cv. Kanadchanka.

The content of dry matter in the raw of investigated plants at the end of vegetation was iden- tified on twenty genotypes and was of 24.76$67.49 \%$ (Fig. 4). The most of dry matter content found in S. laciniatum, PL-3, the least in S. perfoliatum, NRK-7. The total content of sugars in the plants at the end of vegetation was from 2.78 (S. integrifolium, GD-5) to 13.12 (S. integrifolium, GKR-1) \%. This parameter decreased comparing with the period of flowering.

At the end of the vegetation content of ash was in a range from 3.93 (S. integrifolium, cv. Yuvileinyi-90) to 11.2 (S. perfoliatum, PP-1) \% (Fig. 5). The content of calcium and phosphorus in this period was determined as 1.92-5.99 and $0.14-0.86 \%$, respectively.

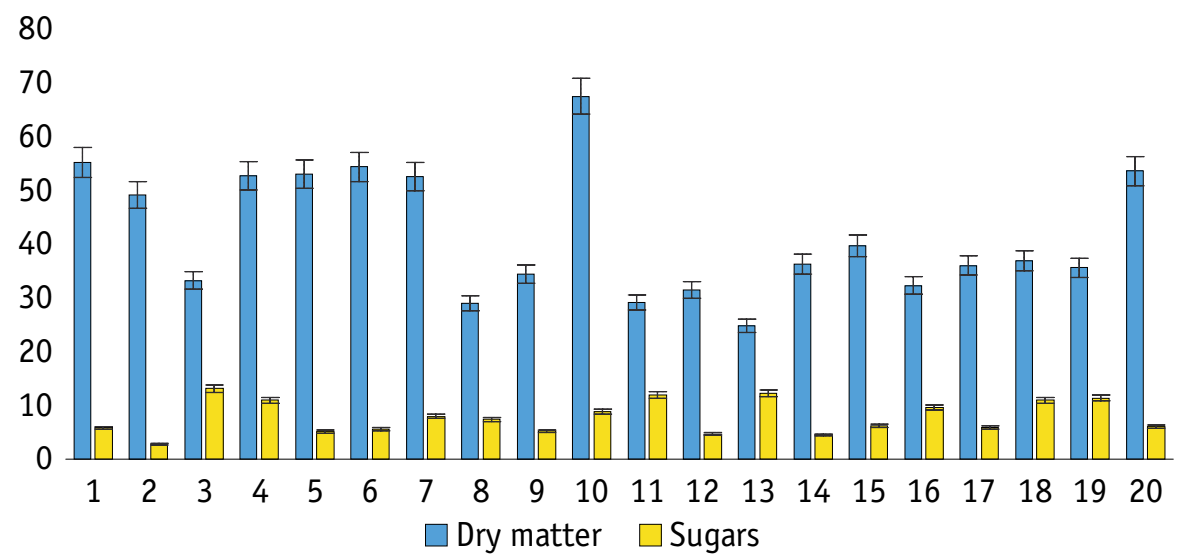

Figure 4. The content of dry matter and total content of sugars in the different genotypes of Silphium L. genus at the end of vegetation, \%

(1 - S. asperrimum; 2 - S. integrifolium, GD-5; 3 - S. integrifolium, GKR-1; 4 - S. integrifolium, cv. Yuvileinyi-90;

5 - S. integrifolium, LPL-4; 6 - S. integrifolium, f. EBSFS; 7 - S. integrifolium $\times$ S. trifoliatum; $8-$ S. laciniatum, f. 2;

9 - S. laciniatum, f. $1 ; 10$ - S. laciniatum, PL-3; 11 - S. perfoliatum, PP-1; $12-$ S. perfoliatum $\times$ S. integrifolium; 13 - S. perfoliatum, NRK-7; 14 - S. perfoliatum, cv. Bogatyr; 15 - S. perfoliatum, cv. Peremozhets; 16 - S. perfoliatum, SR-6; 17 - S. perfoliatum, PP-2; 18 - S. perfoliatum, cv. Kanadchanka; $19-$ S. trifoliatum $\times$ S. integrifolium; $20-$ S. trifoliatum)

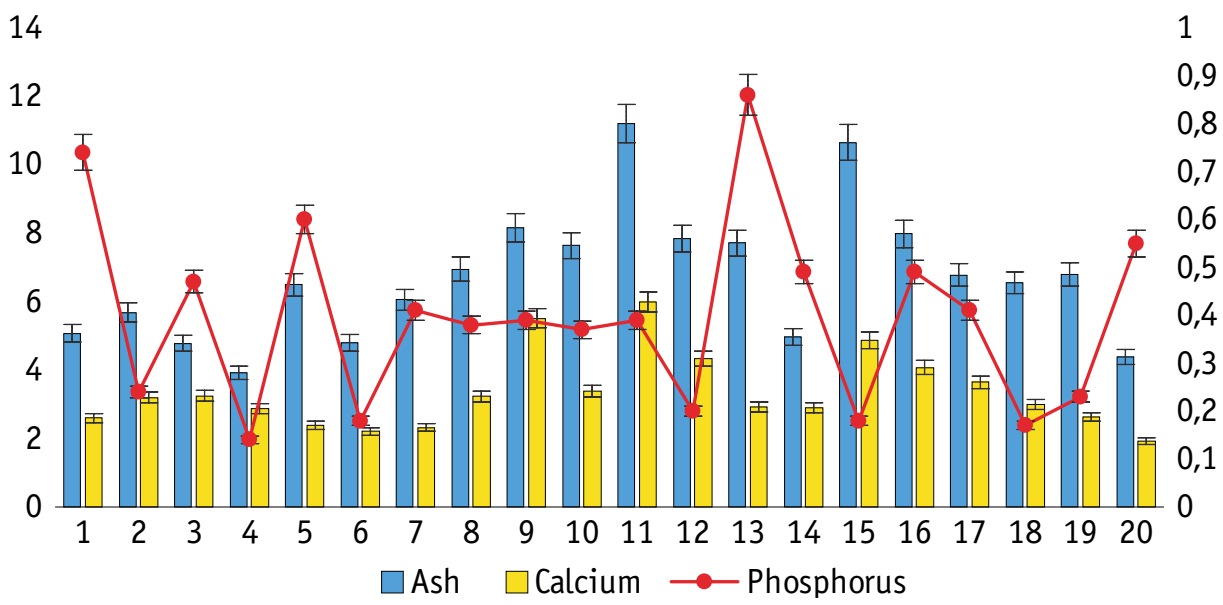

Figure 5. The total content of ash, calcium and phosphorus in the different genotypes of Silphium L. at the end of vegetation, \%

(1 - S. asperrimum; 2 - S. integrifolium, GD-5; 3 -S. integrifolium, GKR-1; 4 -S. integrifolium, cv. Yuvileinyi-90; 5 - S. integrifolium, LPL-4; 6 - S. integrifolium, f. EBSFS; 7 - S. integrifolium $\times$ S. trifoliatum; $8-$ S. laciniatum, f. 2;

9 - S. laciniatum, f. 1; 10 - S. laciniatum, PL-3; $11-$ S. perfoliatum, PP-1; $12-$ S. perfoliatum $\times$ S. integrifolium;

13 - S. perfoliatum, NRK-7; 14 - S. perfoliatum, cv. Bogatyr; 15 - S. perfoliatum, cv. Peremozhets;

16 - S. perfoliatum, SR-6; 17 - S. perfoliatum, PP-2; 18 - S. perfoliatum, cv. Kanadchanka; $19-$ S. trifoliatum $\times$ S. integrifolium; $20-$ S. trifoliatum) 
Comparing with the flowering stage the energetic value of plant raw material of Silphium genotypes at the end of vegetation increased (Fig. 6). In total, the caloricity of raw was from 3153.36 (S. perfoliatum, PP-1) to 3770.28 (S. perfoliatum, cv. Bogatyr) cal $/ \mathrm{g}$.
Its should be noted that results of manyyears investigations demonstrated that phyto raw of many samples of Silphium at the budding-start of the flowering period in selected years energetic value achieved up to $4000 \mathrm{kcal} / \mathrm{kg}$ [14].

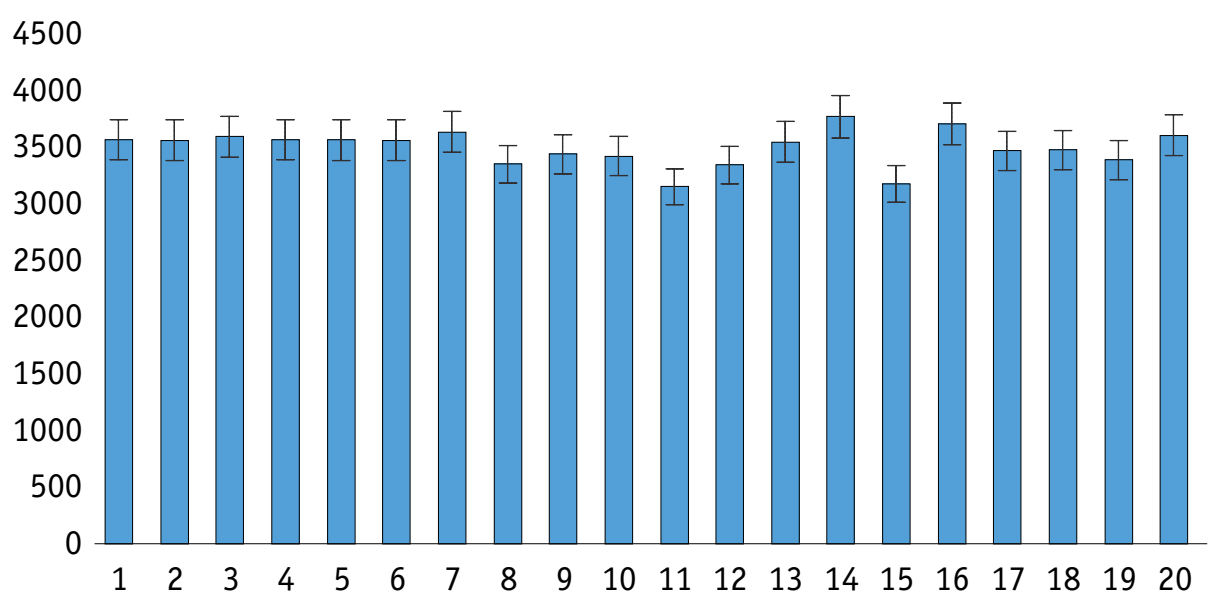

Figure 6. Energetic value of different genotypes of Silphium L. genus at the end of vegetation, cal $/ \mathbf{g}$

(1 - S. asperrimum; 2 - S. integrifolium, GD-5; 3 - S. integrifolium, GKR-1; 4-S. integrifolium, cv. Yuvileinyi-90;

5 - S. integrifolium, LPL-4; 6 - S. integrifolium, f. EBSFS; 7 - S. integrifolium $\times$ S. trifoliatum; $8-$ S. laciniatum, f. 2;

9 - S. laciniatum, f. 1; $10-$ S. laciniatum, PL-3; $11-$ S. perfoliatum, PP-1; $12-$ S. perfoliatum $\times$ S. integrifolium;

13 - S. perfoliatum, NRK-7; 14 - S. perfoliatum, cv. Bogatyr; 15 - S. perfoliatum, cv. Peremozhets;

16 - S. perfoliatum, SR-6; 17 - S. perfoliatum, PP-2; 18 - S. perfoliatum, cv. Kanadchanka;

$19-$ S. trifoliatum $\times$ S. integrifolium; $20-$ S. trifoliatum)

In addition, plants of cup flower provide high yield conditional biofuel (10-5, sometimes till $30 \mathrm{t} / \mathrm{ha}$ ), the energetic value of solid biofuel is $3800-4300 \mathrm{kcal} / \mathrm{kg}$, energetic productivity of plants achieves 40-60 (до 120) Gcal/ha, calculated fuel yield of biogas was 7000-12000 (sometimes to 20000) $\mathrm{m}^{3} /$ ha $[15,35]$.

Collecting of phytomass for biogas and feed conducts at the May-June - first term and after 50-55 days second and more (3-4-times mowing), seeds - September, dry phytomass as an energetic plant - October-November. Plants should be mowed on biogas purpose at budding-start of the flowering stage [15].

Thus, the gene fund of Silphium L. plants that grow in the M. M. Gryshko National Botanical Garden is represented by valuable samples that are sources of high quality of raw for the fodder and energetic purposes. In this case, the most perspective cultivars were $S$. perfolia tum cv. Bogatyr (high content of phosphorus and energetic value), S. integrifolium cv. Yuvileinyi-90 (less content of ash, high yield of dry matter, and energy), S. perfoliatum cv. Peremozhets (high yield of above-ground mass), S. perfoliatum cv. Kanadchanka (high content of protein). S. asperrimum had maximal content of cellulose. The highest content of dry matter had variety S. lacinatum PL-3, sugars - S. perfoliatum SR-6, calcium S. perfoliatum PP-1.

\section{References}

1. Rakhmetov, D. B. (2011). Teoretychni ta prykladni aspekty introduktsii Roslyn $v$ Ukraini [Theoretical and practical aspects of plant introduction in Ukraine]. Kyiv: AgrarMedia Grup. [in Ukrainian]

2. Franzaring, I., Bäuerle, L., Gensheimer, G., \& Fangmeier, A. (2014). Investigation on plant functional traits, epidermal structures and the ecophysiology of novel bioenergy species Sida hermaphrodita Rusby and Silphium perfoliatum L. J. Appl. Bot. Food. Qual., 87, 36-45. doi: 10.5073/JABFQ.2014.087.006

3. Shalyuta, B. V., \& Kostitskaya, E. V. (2018). The yield of Silphium perfoliatum L. depending on the conditions of cultivations. Agric. Eng., 22(2), 91-97. doi: 10.1515/agriceng-2018-0019

4. Britton, N., \& Brown, A. (1970). An Illustrated Flora of the Northern United States and Canada. (Vol. 2). New York: Dover publication Inc.

5. Grunden, R. W. (1960). Biosistematic Studies in the genus Silphium the Perfoliatis jaxa-Muster Jhestis. Ohio: The Ohio State University Columbus.

6. Grunden, R. W. (1962). Combinations in Silphium perfoliatum (Compositae). Constance; Morgantown; West Virginia University, 27(2), 90-91.

7. Uteush, Yu. A., \& Lobas, M. G. (1996). Kormovi resursy flory Ukrainy [Forage resources of Ukrainian Flora]. Kyiv: Naukova dumka. [in Ukrainian]

8. Frączek, J., Mudryk, K., \& Wróbel M. (2011). Rożnik przerośnięty Silphium perfoliatum L. - źródło biomasy do produkcjibiopaliw stałych [Cup plant Silphium perfoliatum L. Biomass Source for Biofuel Production]. Inżynieria Rolnicza, 131, 21-27. [in Polish]

9. Bauböck, R., Karpenstein-Machan, M., \& Kappas, M. (2014). Computing the biomass potentials for maize and two alternative 
energy crops, triticale and cup plant (Silphium perfoliatum L.), with the crop model BioSTAR in the region of Hannover (Germany). Environ. Sci. Eur., 26, 19. doi: 10.1186/s12302-014-0019-0

10. Gansberger, M., Montgomery, L. F. R., \& Liebhard, P. (2015). Botanical characteristics, crop management and potential of Silphium perfoliatum L. as a renewable resource for biogas production. Ind. Crop. Prod., 63, 362-372. doi: 10.1016/ j.indcrop.2014.09.047

11. Schorp, Q., Müller, A. L., Schrader, S., \& Dauber, J. (2016). Agrarökologisches Potential der Durchwachsenen Silphie (Silphium perfoliatum L.) aus Sicht biologischer Vielfalt [Agroecological potential of the cup plant (Silphium perfoliatum L.) from a biodiversity perspective]. J. Kulturpflanzen, 68(12), 412-422. doi: 10.5073/JfK.2016.12.12 [in German]

12. Gansberger, M., Stüger, H.-P., Weinhappe, M., Moder, K., Liebhard, P., Gehren, P., Mayr, J., \& Ratzenböck, A. (2017). Germination characteristic of Silphium perfoliatum L. seeds. Die Bodenkultur, 68(2), 73-79. doi: 10.1515/boku-2017-0007

13. Stadnichuk, N. 0., \& Rakhmetov, D. B. (2012). Introduction of plants of Silphium L. species in Ukraine. In Problemy eksperymentalnoji botaniky ta bitehnolohii [Problems of experimental botanic and biotechnology] (Vol. 1, pp. 48-60). Kyiv: Fitosotsiotsentr. [in Ukrainian]

14. Stadnichuk, N. 0., \& Rakhmetov, D. B. (2014). Energetic potential of plants of Silphium L. genus (Asteraceae) introduced in the M. M. Gryshko National Botanical Garden. In Biolohichni resursy $i$ novitni biotehnologii vyrobnytstva biopalyv: Mizhnar. nauk. konf. [Biological resources and new biotechnologies of biofuel production: Int. Sci. Conf.] (pp. 97 102). Sept. 9-11, 2014, Kyiv, Ukraine. [in Ukrainian]

15. Rakhmetov, D. B. (2018). Netraditsionnye vidy rastenii dlia bioenergetiki [Non-traditional Plant Species for Bioenergetics]. Nitra: Slovak University of Agriculture in Nitra. doi: 10.15414/2018.fe-9788055218557

16. Siaudinis, G., Skuodiene, R., \& Repsiene, R. (2017). The investigation of three potential energy crops: common mugwort, cup plant and virginia mallow on Western Lithuania's Albeluvisol. Appl. Ecol. Environ. Res., 15(3), 611-620. doi: 10.15666/ aeer/1503_611620

17. Fisher, T. R. (1966). The genus Silphium in Ohio. Ohio J Sci., $66(3), 259-263$

18. Wojcińska, M., \& Drost-Karbowska, K. (1998). Phenolic acids in Silphium perfoliatum L. flowers (Asteraceae/Compositae). Acta Pol. Pharm., 55(5), 413-416.

19. Kowalski, R., \& Wolski, T. Evaluation of phenolic acid content in Silphium perfoliatum L. leaves, inflorescences and rhizomes. Electron. J. Pol. Agric. Univ., 6(1). Retrieved from http://www. ejpau.media.pl/volume6/issue1/horticulture/art-03.html

20. Shang, H.-M., Zhou, H.-Z., Li, R., Duan, M.-Y., Wu, H.-X., \& Lou, Y.-Y. (2017). Extraction optimization and influences of drying methods on antioxidant activities of polysaccharide from cup plant (Silphium perfoliatum L.). PLOS ONE, 12(8), e0183001. doi: 10.1371/journal.pone.0183001

21. Kowalski, R., \& Wierciński, J. (2004). Evaluation of chemical composition of some Silphium L. species seeds as alternative foodstuff raw materials. Pol. J. Food Nutr. Sci., 54(4), 349-354.
22. Rakhmetov, D. B., Korablova, 0. A., Stadnichuk, N. 0., Andrushchenko, 0. L., Kovtun-Vodyanytska, S. M., Revunova, L. G., .. Bondarchuk, 0. P. (2015). Kataloh roslyn viddilu novyh kultur [Catalogue of plants of New Culture Department]. Kyiv: Fitisotsiotsentr. [in Ukrainian]

23. Dospekhov, B. A. (1985). Metodika polevogo opyta (s osnovami statisticheskoy obrabotki rezul'tatov issledovaniy) [Methods of field experiment (with the basics of statistical processing of research results)]. (5 ${ }^{\text {nd }}$ ed., rev. and enl.). Moscow: Agropromizdat. [in Russian]

24. Hrytsaienko, Z. M., Hrytsaienko, A. 0., \& Karpenko, V. P. (2003). Metody biolohichnykh ta ahrokhimichnykh doslidzhen roslyn $i$ gruntiv [Methods of biological and agrochemical investigations of plants and soils]. Kyiv: Nichlava. [in Ukrainian]

25. Pochinok, Kh. N. (1976). Metody biokhimicheskogo analiza rasteniy [Methods of biochemical analysis of plants]. Kyiv: Naukova dumka. [in Russian]

26. Krishchenko, V. P. (1983). Metody otsenki kachestva rastitel'noy produktsii [Methods for evaluating of quality of plant production]. Moscow: Kolos. [in Russian]

27. Zheng, Q., Zhou, T., Wang, J., Cao, X., Wu, S., Zhao, M., ... Guan, X. (2018). Pretreatment of wheat straw leads to structural changes in improved enzymatic hydrolysis. Sci. Rep., 8, 1321. doi: 10.1038/s41598-018-19517-5

28. Zamowski, R., \& Suzuki, Y. (2004). Expending Soxhlet extraction of resorcinolic lipids from wheat grains. J. Food Compos. Anal., 17(5), 649-663. doi: 10.1016/j.jfca.200309.007

29. Rakhmetov, D. B., Vergun, 0. M., Stadnichuk, N. O., Shymanska, 0. V., Rakhmetova, S. 0., \& Fishchenko, V. V. (2019). Biochemical study of plant raw material of Silphium L. spp. in M. M. Gryshko National Botanical Garden of the NAS of Ukraine. Introdukciâ roslin [Plant Introduction], 83(3), 80-86. doi: 10.5281/zenodo.3404144

30. Bury, M., Możdżer, E., Kitczak, T., Siwek, H., \& Włodarczyk, M. (2020). Yields, calorific value and chemical properties of cup plant Silphium perfoliatum L. biomass, depending on the method of establishing the plantation. Agronomy, 10(6), 851. doi: 10.3390/agronomy10060851

31. Kowalski, R. (2007). Silphium trifoliatum L. - a new alternative cultivation herbal plant. Acta Agric. Scand. B Soil Plant Sci., 57(2), 155-166. doi: 10.1080/09064710600766503

32. Monti, A., Di Virgilio, N., \& Venturi, G. (2008). Mineral composition and ash content of six major energy crops. Biomass Bioenerg., 32(3), 216-223. doi: 10.1016/j.biombioe.2007.09.012

33. Prochnow, A., Heiermann, M., Plöchl, M., Amon, T., \& Hobbs, P. J. (2009). Bioenergy from permanent grassland - a review: 2. Combustion. Bioresour. Technol., 100(21), 4945-4954. doi: 10.1016/j.biotech.2009.05069

34. Moskalenko, A. M., \& Popova, N. V. (2018). Research of mineral composition of Helichrysum bracteatum herbal drugs. Ukr. biofarm. ž. [Ukr. Biopharm. J.], 1, 72-76. doi: 10.24959/ubphj.18.160

35. Blume, Ya. B., Hrygoriuk, I. P., Dmytruk, K. V., Dubrovin, V. 0., Yemec, A. I., Kaletnyk, H. M., ... Tsygankov, S. P. (2014). Systema vykorystannia bioresursiv u novitnih biotehnologiiah otrymannia alternatyvnyh palyv [System of use of bioresources in new biotechnologies of obtaining alternative fuels]. Kyiv: Agrar Media Grup. [in Ukrainian]

УДК 582.998: (581.192+631.55)

Рахметов Д. Б., Вергун 0. М., Рахметова С. О., Шиманська 0. В., Фіщенко В. В. Вивчення деяких біохімічних параметрів і продуктивності генотипів Silphium L. як перспективних енергетичних культур. Plant Varieties Studying and Protection. 2020. T. 16, № 3. C. 262-269. https://doi.org/10.21498/2518-1017.16.3.2020.214927

Національний ботанічний сад імені М. М. Гришка НАн України, вул. Тимірязєвська, 1, м. Київ, 01014, Україна, *e-mail: jamal_r@bigmir.net

Мета. Це дослідження мало на меті визначити деякі біохімічні параметри та продуктивність генофонду рослин роду Silphium L. у Національному ботанічному саду імені М. М. Гришка НАН України. Методи. Рослинна сировина Silphium досліджена у фазі квітування (17 генотипів) та в кінці вегетації (20 генотипів). Уміст поживних речовин під час квітування вивчено у 3 видів та 4 сортів рослин. Визначення вмісту сухої речовини, золи, кальцію, безазотистих екстрактивних речовин проводили за Грицаєнком і співавт. (2003), фосфору, білка - за Починок (1976), цукрів - 
за Крищенко (1983), целюлози - за Zheng et al. (2018), ліпідів - за Zamowski, Suzuki (2004). Були визначені параметри продуктивності рослин: урожайність наземної маси, вихід сухої маси, енергетична цінність сировини та вихід енергії з одиниці площі. Дані аналізовані статистично. Результати. Дослідження вмісту поживних речовин показало, що вміст сухої речовини знаходився в межах 18,90-29,3\%, білка - 8,88-23,56, целюлози - 15,10-36,14, золи - 8,13-12,19, ліпідів - 1,83-3,97\%; урожайність наземної маси - 45,0-139,0 т/га, вихід сухої речовини 10,31-36,92 т/га,енергетична цінність фітосировини - 39334249 кал/г, вихід енергії з урожаєм - 43,81-149,27 Гкал/га. Дослідження генотипів у період квітування та в кінці вегетації дало змогу виявити, що вміст сухої речовини в усіх зразках становив 18,38-67,49\%, цукрів - 2,78-19,0, золи - 3,93-11,20, кальцію - 1,68-5,99, фосфору - 0,141,21\%, енергетична цінність - 3153,36-3770,28 кал/г. Висновки. Рослинна сировина генотипів Silphium L. spp. $€$ цінним джерелом поживних речовин. Уміст золи, тї̈ компоненти, енергетична цінність та параметри продуктивності залежить від генотипу та періоду росту й розвитку рослин. Результати досліджень дають змогу рекомендувати деякі генотипи Silphium як перспективні енергетичні культури в Україні, а також інших країнах.

Ключові слова: Silphium L.; генотипи; енергетична цінність; продуктивність; зола.

Надійшла 19.08.2020

Погоджено до друку 16.09.2020 